Seton Hall University

eRepository@Seton Hall

Library Publications

University Libraries

2007

\title{
Transgression or Stasis? Challenging Foucault in LIS Theory
}

John Buschman

Follow this and additional works at: https://scholarship.shu.edu/lib_pub

Part of the Library and Information Science Commons

\section{Recommended Citation}

Buschman, John, "Transgression or Stasis? Challenging Foucault in LIS Theory" (2007). Library Publications. 66.

https://scholarship.shu.edu/lib_pub/66 
Transgression or Stasis? Challenging Foucault in LIS Theory

by

John Buschman

Professor - Librarian and Department Chair, Rider University Library, 2083 Lawrenceville Road, Lawrenceville, New Jersey 08648 e-mail buschman@rider.edu.

Submitted to Library Quarterly 
Transgression or Stasis? Challenging Foucault in LIS Theory 


\begin{abstract}
Within the project of constructing a critical theory of library and information science
\end{abstract} (LIS) or librarianship ${ }^{1}$, Michel Foucault (1926-1984) is one of the primary thinkers informing this work. He is widely cited in this LIS work and his insights are adapted in various ways which focus on LIS forms of power, discourse, etc. Other thinkers have focused on Foucault's topics, yet it is Foucault who is far more central to the project at hand. Librarianship has taken up the challenge set down previously to more fully explore his work, and having responded to that challenge, it is now time to look more carefully at the implications of Foucault's thinking as a foundation for a critical-theoretical LIS. His work has undergone extensive analysis and critique, and this article is a similar first step within LIS. While not a comprehensive review of every Foucauldian idea that has filtered into the literature, a review of common themes utilized by a core group of LIS authors is undertaken. The paper will then turn to critiques of and problems in Foucault's thinking since it is the contention here that, by relying on Foucault's insights for a line of analysis and research, this LIS theoretical work will reflect some of those problems.

${ }^{1}$ A critical theory of LIS/librarianship refers to efforts to explore various theoretical and philosophical positions and their meaning in the spirit of critically uncovering and exposing to scrutiny the hidden assumptions guiding work and research - much of which is broadly grounded in a critique of positivism [1]. The terms librarianship and LIS are used here interchangeably. They are inclusive of the people and institutions of the three traditional areas of public, academic and school libraries as well as those who research and theorize about them. This is an inherent argument against common artificial divisions between practice, theory, and research. Lastly, a definitional note on the use of the terms theory/theoretical is also needed. A helpful recent study on the use of theory in the LIS literature reviews many working definitions of the term, but casts "'theory' as broadly as possible [to] capture its widest range of use" by including articles in which a theory was simply mentioned several times [2, p. 65]. I adapt Wolin [3, pp. $1969,1080]$ : it is not enough to cite "commonplaces, viz., that facts are senseless without theoretical concepts, or that the meaning which facts acquire from a theory is purchased at the price of shaping the facts by the theoretical perspective employed." Rather, the important distinction for him is that the problem "be a truly theoretical one," that is, not "technical in nature [or] the most expeditious means of achieving goals ... agreed on beforehand." Wolin argues that theory should be concerned with the "'systematically mistaken': mistaken arrangements and wrong action [like] injustice, alienation, and exploitation [which are not] random consequences of a system but [rather consequences of an] extensive set of [problems] which can be confidently expected to continue." Theoretical work in response "seeks to displace" the systematically mistaken, often ending in radical critique. 


\section{Introduction}

Michel Foucault (1926-1984) stands as one of the primary wellsprings informing the project of constructing a viable, critical theory of library and information science (LIS) or librarianship. He is widely cited and his insights are adapted in various works which focus on LIS forms of power, discourse, archaeology, silences, exclusion, defining the "other," domination and micropractices in the last fifteen years of critical-theoretical LIS scholarship [see for example $4 ; 5 ; 6 ; 7 ; 8 ; 9 ; 10$ ]. For instance, this journal, in issuing a call for papers (CFP) on "discursive approaches to information seeking in context" for a future issue, is sponsoring a line of analysis heavily influenced by Foucault. Noting that "in recent years, LIS researchers have begun to explore ... how people give accounts of their information behavior or construct the meanings of technical artifacts in work and everyday life," the CFP stated the importance of studying "how information practice $[\mathrm{s}]$ are constructed in discourse ... from a broader sociological perspective" [11].

Primary Foucauldian ideas like discourse, socially-constructed knowledge, and artifacts are embedded in that CFP. Foucault described discursive practices as "not purely and simply ways of producing discourse. They are embodied in technical processes, in institutions, in patterns for general behavior, in forms for transmission and diffusion, and in pedagogical forms which, at once, impose and maintain them" [12, p. 200; see also 13, p. 38]. The concept is understood here as "the intertwining of ... non- 
documentary practices ... with language, symbols, drawings, shop talk, ideologies, and the production of documents" [6, p. 231]. Similarly, the reference to socially constructed knowledge and practices utilizes Foucault's analysis of the human sciences: "Beneath the increasing leniency of punishment [is] a whole new system of truth and a mass of rules hitherto unknown in the exercise of criminal justice. A corpus of knowledge, techniques, 'scientific' discourses is formed and becomes entangled with the practice of the power to punish" [14, pp. 22-23]. Finally, in studying particulars and the constructed meanings of artifacts in everyday life, Foucault's concern with silences and what has been overlooked $[15 ; 16]$ - allowing obscure police and prison manuals and medical texts or institutional architecture to "speak for themselves" - is echoed. That is, they are to "be viewed without resort to the subject ... reveal[ing] a level of intelligibility all their own" [17, p. 143, see also pp. 142-147; 18, pp. 65-71]. By looking at the mundane (informationally speaking) and analyzing how we construct our practices and invest our artifacts, we construct knowledge from the bottom up, unconcerned with understanding wholes or logical systems, but rather "features that help to reverse the traditional strategy of searching for continuities" [17, p. 145; 13]. The CFP represents a line of questioning and research deeply influenced by Foucault's work and consequent influence in librarianship, whether in the foreground or background.

Plenty of other thinkers have focused on Foucault's philosophical turf like text, power, exclusion, language, representation, communication, and the incommensurate and fragmented nature of knowledge. Derrida, Wittgenstein, de Saussure, Lyotard, 
Baudrillard, Deleuze, Lacan, Rorty, and Barthes are the core thinkers usually linked with $\operatorname{him}[18 ; 19 ; 20 ; 21]$. Yet it is Foucault who is far more central to the project at hand. For instance de Saussure's work on language as a representational system (signifiers) is cited in an article on cultural studies and librarianship's image. His ideas are filtered primarily through the work of Stuart Hall, who makes the key linkage between Foucault's work and stereotyping and power. While de Saussure and Foucault are both equally cited, it is Foucault's notions of analyzing representation ("media stereotypes of librarians ... that ultimately constricts the power and economic status of a gendered profession") which drives the analysis in the article [22]. Much the same can be said of another work already cited here: while Lyotard and Baudrillard are both included, it is Foucault's work on discourse - again cited but also filtered through Mark Poster, Nancy Fraser, and Marike Finlay [4, pp. 367-368] - which informs the analysis. The point is not to ferret out each instance of Foucault's "hidden" influence in critical-theoretical LIS work, but rather to note that it is Foucault - not those commonly linked with him - who has much the greater influence. For instance, two recent studies place Foucault at the core of this effort: Pettigrew and McKechnie's study identifies a body of work centered on theory in the humanities where Foucault and closely related concepts and thinkers predominate $[2, \mathrm{p}$. 72], while Day [23] places Foucault at the center of deconstructive theory in LIS.

A core group in librarianship has seemingly taken up the challenge laid down by Harris [24] and Wiegand [25] to more fully explore Foucault's work, and having responded to that challenge, it is now time to look more carefully at the implications of 
his thinking, which has undergone extensive review, analysis, and critique. This article is a first step in this vein within LIS. This will not be a comprehensive review of every Foucauldian notion or citation of his work that has filtered into the literature, but rather a review of common themes utilized by that core group of LIS authors involved in the aforementioned project. Their work: 1) utilizes or explores Foucault's ideas prominently; 2) appears primarily in the most prestigious journal venues of theory (in the study cited earlier [2] - and thus is widely cited and influential); 3) avoids methodological approaches via constructivist (social or otherwise), user studies, and notions of "seeking" which run afoul of Foucault's epistemological critiques of subject/object, content, and agency and lead to positivism [23]. The paper will then turn to critiques of and problems in Foucault's thinking since it is the contention here that, by relying on Foucault's insights for a line of analysis and research, this theory of librarianship will reflect some of the problems in his work.

\section{Foucauldian Themes in LIS}

This review and sampling of Foucault in librarianship will not escape the problem Walzer identified: a constructivist reconstruction of Foucault since he "never presented [his ideas] in anything like a systematic fashion," his ideas overlap, and one must ignore certain self-denials. For instance, despite Foucault's participation in the radical deconstruction of the meaning of "author," he simply "takes him to be an author in the conventional sense" making arguments and claims to plausibility with acolytes who 
conventionally pursue research agendas along lines laid out by his authored writings [26, pp. 193-94]. Poster also notes some of the same basic issues [17, p. 152]. Second, this review will not be an intramural disagreement regarding the "correct" interpretation of Foucault, but rather in the spirit of its subject, will take this appropriation on its face as a discourse. Given these two caveats, his ideas as appropriated and used in LIS criticaltheoretical work will be grouped here in four thematic areas: discourse, power/ knowledge, fantasia, and genealogy/archaeology. Before taking up these themes, it is worth noting that one common, overriding use of Foucault's thinking in this literature that of the critique of positivism and instrumental reason - will not be reviewed since it is a subject extensively covered already [see the summary of summaries in 1] and need not be repeated here.

\section{Discourse}

The single most influential idea in LIS theoretical work appropriated from Foucault is discourse - noted earlier and restated here as "practices that systematically form the objects of which they speak" [18, p. 70]. It is discourse in this Foucauldian sense which has been around in this literature the longest, primarily as a form of critical self-reflection. For instance, Frohmann [27, pp. 120-121] has long argued the salience of discourse analysis, which 
takes discourse as its object of analysis.... LIS-talk is a set of serious speech acts [which are] performed by institutionally privileged speakers.... From at least 1876, to the present day, the discourses of LIS are thoroughly intertwined with specific institutional forms through which power over information, its users, and its uses is, has been, and will continue to be exercised.

From this basis he moved on to argue for a connection between discourse and documentary practices in librarianship, building on another of Foucault's insights on the documentation of surveillance and its part in the "mechanisms of discipline" [Foucault in 28, p. 18]. Frohmann has since critically focused on discourse and documentary practices and the resulting authority invested in science, information science, and LIS's role in privileging instrumental epistemologies, definitions, and forms of knowledge which obscure the operation of power $[4 ; 6 ; 27 ; 28]$. "LIS theory is so extraordinarily unreflective about its institutional underpinnings to warrant the hypothesis that power's invisibility is the consequence of a deliberate discursive strategy" [4, p. 368].

Radford (with different coauthors at various times) has explored similar ideas: "The key to understanding the production of scientific knowledge is not the phenomena comprising the world but the prevailing systems of ... discourse in which certain propositions about the world can count as objective and others cannot" [29, p. 417]. However, it would be fair to characterize Radford over the years as focused more on 
specific library practices and images of libraries/librarians as the discourse to be unpacked. For instance, he often cites as a basis of analysis libraries' organized collections of texts and the "ensemble of rules [by] which the true and false are separated" [29, p. 418; see also 5; 7] or the contrasts between the library-as-discourseunder-control/surveillance and the power embedded therein and the (sometimes) contrasting media discourse of stereotyped images of librarians $[22 ; 30]$. He is the author most explicitly concerned with explaining Foucault and his meaning for the field, and arguing that discourse "itself [i]s a legitimate object of inquiry," going on to write in the article he wrote about the article he had written that was being read at that moment: "what is important is not what [a prior] sentence means, but that it has appeared in this article." Radford explains that all these together form a Foucauldian "statement," and their importance is not their veracity, but rather their existence in relationship to one another and "the conditions in which texts appear" [7, pp. 4, 11]. Used simultaneously as a tool/method and as a way to define various texts/statements/speech acts as objects of study, Foucauldian discourse analysis is often argued to be a means to achieve reflexive practice in the field [see also $8 ; 31 ; 32$ ].

Power/Knowledge

It can not have escaped notice that tightly interwoven with discourse is the relationship to power and knowledge - themselves tightly interwoven in Foucault's thought: 
A society without power relations can only be an abstraction [33, p. 791].

$[\mathrm{T}]$ he development of ... branches of knowledge can in no way be dissociated from the exercise of power. [T] he fact that societies can become the object of scientific observations, that human behavior became ... a problem to be analyzed and resolved ... is all bound up ... with mechanisms of power. [T] he birth of the human sciences goes hand in hand with the installation of new mechanisms of power. ...Indeed, truth is no doubt a form of power [34, pp. 106-107].

Power and knowledge directly imply one another ... there is no power relation without the correlative constitution of a field of knowledge, nor any knowledge that does not presuppose and constitute at the same time power relations [14, p. 27; see also 35].

Over and over again in the work under review here, LIS theory and research and everyday practices in librarianship are cited as prime examples of Foucauldian power and the masked workings of authority via knowledge in the field - particularly in view of the traditional claim of neutrality/objectivity. For example: "the effects of ... positivist approaches are clearly discernable [in that] the profession embraced the ideals of neutrality and objectivity and sought to formulate laws and generalizations applicable to 
library-related activities." It was via "Foucault's analysis of power and knowledge ... that the constitution of 'a specific field of knowledge is [now viewed as] a political act which simultaneously configures a field of ignorance'" [9, pp. 221, Frohmann in 229, see pp. 229-230 for a summary review and $4 ; 5 ; 6 ; 7 ; 27 ; 29 ; 36 ; 37$ for examples].

The previously-mentioned organization of texts is an emblematic theme concerning power/knowledge, often directly citing Foucault's comments on the "tight enclosures" of libraries and/or the legitimating system of books, publishing, and libraries [36, p. 320; see also 29; 38; 39; 6, pp. 255-257]. Finally, Radford has explored the related power theme of librarian/library stereotyping and fear via a line of analysis grounded in Foucault $[5 ; 22 ; 30]$. Unattractive and disempowered stereotypes are seen themselves as an exercise in power (or "symbolic violence"), ironically/contradictorily played off against the "dangers" of uncontrolled discourse that libraries are culturally meant to be a bulwark against. The ironies run both directions here since libraries/ librarians exercise power via the organizing principles/violence of the institutions, but are themselves disempowered. Power - and what constitutes professional knowledge and practice - becomes a key element to be uncovered (usually through an analysis of discourse).

Fantasia 
Another specific idea pulled from Foucault is the notion of "the fantasia of the library" based on his close reading Flaubert's The Temptation of Saint Anthony [40, pp. 87-109] revealing "reason in the form of hallucination, dreams in the form of scholarship and, as such, both aspects are significantly weakened" [38]. In Frohmann's analysis, it is science that is a fantasia produced by the library's (and LIS theory's) organization of its discursive regime. Foucault demonstrates that beneath the appearance of religious rapture or frenzy in Flaubert's work on Saint Anthony stands "meticulous erudition" that constitutes a commentary on the library, the proliferation of texts, and the relationships between them [6, p. 256-258]. Both Radford and Frohmann come to similar conclusions: "madness creeps into the order of the library and the library orders the madness of hallucination" [38]. New texts bring new orders, new possibilities, new worlds (fantasias) as texts influence the reading of other associated texts, and this becomes the provenance of - and contradiction within - libraries, which after all, seek to “institutionalize particular arrangements of texts" [29, p. 420]. While Frohmann and others $[6 ; 36]$ utilize this metaphor and analysis to uncover and decenter the epistemology and text of science and LIS, Radford argues that this represents a fruitful epistemology to open up possibilities heretofore precluded in librarianship's discourse - like the worth of less-credited texts and the insights of unindocrinated library users [29;38].

Genealogy/archaeology 
Like power/knowledge, the concepts of genealogy and archaeology are much intertwined in Foucault:

I am working on a history of science that ... seeks to discover the discursive, the institutional, and the social practices from which these sciences arose. This would be an archaeological history. [D]iscover[ing] the point at which these practices became coherent reflective techniques [and] a particular discourse emerged from those techniques and came to be seen as true, the point at which they are linked with the obligation of searching for ... and telling the truth ... is to construct a genealogy of the subject. The method is an archaeology of knowledge... [41, p. 223].

Simons notes that Foucault conceptually moved from the "task of archaeology" to "genealogical critique ... to characterize his historical studies." His archaeologies looked at "the form of power that makes individuals subjects" via the development of the human sciences [42, pp. 187-189], while his genealogies are "attempts to reconstruct the origins and developments of discourses by showing their rootedness in a field of forces" [19]. The contingency and "fragility of historical forms" [18, p. 64] are his specific targets, but they are embedded in his dispute with larger themes of Western thought like the supposition of "'the subject'[:] an objectively stable and sovereign ego [as] both the source and basis for all knowledge [and] transhistorical forces, like the capital of Marx or 
the unconscious of Freud" [43]. Like Foucault, the LIS literature which makes use of these terms also elides them, so both are subsumed under this brief discussion.

Budd [10, pp. 9-13] adapts Foucault's genealogy as the term to describe his overall project of "illustrat[ing] the various branches [of LIS thinking and philosophy] from the main line, thus demonstrating the variability of thought" situated within the aforementioned critique of positivism. While he notes disagreement with Foucault on some issues (like the existence of truth), he still finds the concept compelling and highly useful: "influence is not simple.... All thought is part of the genealogy, and, while there may be competition or suppression, there is also the possibility to assess merit on the grounds of reason and intellectual soundness [and] the present project does attempt to find at least some hint at origins of the current mode of thinking in LIS...." In turn, Radford [7, pp. 16-17] advocates an "archaeology of LIS" with similar goals: "what Foucault adds to this understanding of the field's past is the realization that invoking this history is not meant to simply tell us how LIS came to be the way it is." Examining the past is an attempt to understand and disturb and transgress the boundaries, definitions and shape of the present in this formulation. Coming full circle, Radford [38] previously invoked prior work of Budd's [37] to argue for a shifting of thought, discourse and research via interrogating purposes and assumptions via Foucauldian analytical forms.

This review does not purport to represent the entirety of Foucault's ideas in librarianship's critical-theoretical literature. For instance, the relationship between 
documentary practices, the surveillance/disciplinary society, and "micropractices as relays of institutional power" [6, pp. 262-263] represents a form of Foucauldian analysis concerning the "unrelenting expansion of rationalized systems of administration and social control ... interiorized to the point that each person is his or her own overseer" [ $[18$, pp. 80,74]. The concepts are clearly related to those already reviewed, but it is not yet a widespread theme in this literature. Nor was the goal to again put the positive case for his ideas and their efficacy and application to librarianship and its theoretical bases - that has already been thoroughly done. Rather, this review established Foucault's central influence and described it in broad themes present in the core critical-theoretical literature. Since "conceptual imports bring with them discursive strategies" - and therefore embedded problems and forms of power as one of the authors already reviewed has noted [27, p. 123] - the task now turns to reviewing the critiques of Foucault of relevance to LIS.

\section{Against Foucault}

What are the problems that the conceptual importation of Foucault into LIS theory brings with it? The place to begin is with Jurgen Habermas's [44; 45] critique of Foucault. Habermas takes him seriously as a thinker and thus bothers to trace both the antecedents and the consequences of his work: 
The spatial metaphor of inclusive and exclusive reason reveals that the supposedly radical critique of reason remains tied to the presuppositions of the philosophy of the subject from which it wanted to free itself. [I]nside and outside are linked with domination and subjugation [and] thus, the other of reason remains the mirror image of reason in power [45, p. 309].

The potential for excitement, stylized into the other of reason, becomes at once esoteric and pseudonymous; it comes up ... as a turning point in the archaeology of the human sciences for Foucault.... Whether in the form of meditative thought or of genealogy, Heidegger and Foucault want to initiate a special discourse that claims to operate outside the horizon of reason without being utterly irrational [45, pp. 307-308 (emphasis in original)].

Foucault did not think through the aporias of his own approach [in that] his theory tries to rise above [the human] pseudo-sciences to a more rigorous objectivity, and ... gets caught all the more hopelessly in the trap of a presentist historiography, which [is] compelled to a relativists selfdenial and can give no account of the normative foundations of its own rhetoric. [The resulting] presentism, relativism, and cryptonormativism are the consequences of his attempt to preserve the transcendental moment 
proper to generative performances in the basic concept of power while driving from it every trace of subjectivity [45, pp. 295-296].

The radical critique of reason extracts a high price for taking leave of modernity 45, [p. 336].

Habermas repeatedly traces and establishes the links between Foucault and other thinkers, placing him in a continuum from the Romanticism/nihilism of Nietzsche on through the "scurrilous game" of Derrida's deconstruction and the "counterdiscourse" of modernity [45, pp. 309-310, 266-270; 46, pp. 81-82]. The result is a "theor[y] which grasp[s] the whole as untrue, and offer[s] the impossibility of escape as the only affirmation possible ... match[ing] the mood of the critique of civilization" - a profoundly neoconservative position in his view [46, p. 81; 47; see also 21, pp. 102-103]. It is his negations - anti-Enlightenment, anti-modernity, anti-Marx, anti-Freud, anti-truth, anti-logocentrism, etc.- which define Foucault. Foucauldian individual action, such as it is, is aptly named by John Tate [48] as an "ethic of transgression." If there is no separate "self" - only that which is constituted by the discourses which dominate it - then human freedom is foreclosed. There will only arise another discourse to define, control, and dominate the individual who has no particular reason to transgress $[48 ; 49 ; 50]$. Foucault never reconciled his assertion that his work was to "give new impetus ... to the undefined work of freedom" [51, p. 46] with statements that he "did not think that it is possible to say that one thing is of the order of 'liberation' and another is of the order of 
'oppression'... I do not think that there is anything that is functionally -- by its very nature -- absolutely liberating" [52, p. 245], or his rejection of "the idea that under power with its acts of violence, and its artifice, we should be able to rediscover the things themselves in their primitive vivacity" [53, p. 119]. This issue - much simplified here - stands only first among the objections of Foucault's critics. They note a host of contradictions and gaps like the lack of a clear epistemology or methodological protocols with which to ground and thus evaluate his work, etc. [26; 49; 50; 54; 18, pp. 88-95]. However, beyond the significant implications of his nihilism, Foucault's contribution to a critical theory of librarianship contains specific issues which also bear examination: issues of text, and conceptions of power.

Text

Put simply, Foucault conflated many "texts" and thus forms of discipline, power, and their objects. Kumar places him within the continuum that "proclaims that the concept of 'textuality' applies to the world, not just the book." [21, p. 103; see also 19; 23 , p. 592]. Similarly, Poster traces the rooting-out of logocentrism and anthropomorphism in Foucault's designation of documents as "monuments" to be studied as "large-scale social phenomena" via his radical decentering (or simple ignoring) of "the subject" (author/designer, etc.) and their intentions. It is through these definitions and textual methods that these "monuments" speak for themselves and reveal their own internal logic [17, pp. 143-144]. "Texts" - that is, discursive formations, discourses, 
neglected tracts, institutional designs, manuals of direction and procedure, and social formations and organizations all intertwined in/with power and knowledge - become something to be "read" and traced archaeologically and genealogically in the Foucauldian sense.

Walzer notes that Foucault is highly selective in the texts he chooses to read, steering clear of actual people and their experiences and preferring to remain in the realm of rules, plans, designs, and regulations. The result is two problems. First, "subjection to ... control is not the same thing as being in prison: Foucault tends to systematically underestimate the difference." Second, physical and intellectual disciplines "are radically entangled," enabling the complete equation of knowledge with the imposition of power [26, p. 199-201]. Foucault thus conflates the demise of the "transcendental subject" of history with the lack of "knowledgeable human subjects" - the second having "cardinal significance" in Giddens' view [55, pp. 222-223]. He goes on to echo Walzer in criticizing Foucault's equation of the prison with the factory, and his denigration of bourgeois freedoms which "have turned out to be very real ... in the light of ... totalitarian societies" and formal rights (however incomplete) which allowed labor to organize and exert political influence. Foucault turns this on its head: since totalitarianism exists/ existed, it must be implicated in the systems and discourse which make us "free." "Freedom" is therefore a masked discourse/text of domination/discipline/control, of which we are unaware and cannot transcend. 
On the matter of the textual "death of the subject," feminists and minorities have been quite pointed: "Why is it, exactly at the moment when so many of us who have been silenced begin to demand the right to name ourselves, to act as subjects rather than objects of history, that just then the concept of subjecthood becomes 'problematic'? ... And why is it only now that critiques are made of the will to power inherent in [our] effort to create theory?" [Hartsock in 56, p. 24] This is a point echoed repeatedly: this theoretical construct and its language "is as hegemonic as the world it attacks.., surfac [ing], interestingly enough, just when the literature of peoples of color, black women, Latin Americans, and Africans began to move to 'the center"' [57, p. 71]. Speaking truth to power - sometimes the only means of effective resistance for the less-powerful, frequently done via the creation of their own, alternate "texts" - becomes merely an effect of power itself in Foucault's terms [58, p. 46, see also p. 52]. (This clearly echoes Habermas's contention that Foucault's thinking inadvertently ends in a form of neoconservatism.) Closely related is the notion that there are two Foucaults. The first is Continental, firmly grounded in intellectual arguments with Freud and the discursive construction of mental illness, Marx and the transhistorical subject of the proletariat, and questions of the historical "sovereign." The second was the American Foucault appropriated by literary theorists to read and still further deconstruct texts and discourses in disciplines - including the language of literary analysis. In this, however seemingly subversive, "the traditional apparatus of textuality is affirmed and the sanctity of the kinds of things done under the rubric of literary criticism is reinforced" [19; see also 26, 
pp. 194-195; 43]. It is the American/lit-crit Foucault - and the consequent freezing of academic and literary hierarchies - which is so poignantly protested above.

Power

If the preceding discussion overlapped this category, it is worth reminding ourselves again that Foucault's concepts are tightly entangled in his thinking (imbricate is a favorite word to describe this effect). It is nonetheless worth examining commentary on/critiques of his concept of power as a separate genre. Poster observes that he does not reduce discourse to a "material or social referent but constitutes it within the play of power... Discourse does not act at the behest of power. It is power." He goes on to note two serious problems. First, in this formulation of discourse/power, Foucault makes at base a positivist argument which he does not adequately address: his "new categories fit the data better than the old ones." Second, Foucault poses conflicting claims concerning discourse/power analysis to the specific rise of the social sciences and/or as a general theory of history. The first is limited - obviating his general claims concerning the nature of power. The second is a challenge to Marxism (displacing the centrality of the class and the means of production) in a "new formulation of power [as] a central vehicle of social control, and ... a means to comprehend and undo it." However, thus constructed it is radically ahistorical, for instance equating the confessional of four hundred years ago with the contemporary psychotherapy session. The result evacuates "differentiat[ions 
between] historical epochs by the form, not just the content, of their discursive practices" [17, pp. 148-151].

To Poster's two problems must be added a third: the problem which arose in the attempt to dethrone Marxism. If power so reconceptualized has no subject (the proletariat, the bourgeoisie, the sovereign) and is in fact a "network of relations in which we are all always and everywhere enmeshed" [59, p. 54], then there is no point to or means of opposing or toppling the state or the economic system. There is no commodity of power to be seized; it has no origin or source. Foucault attempts a way out by claiming that power produces resistance [60, pp. 205-217], but the larger question is thus begged again: how, why, and toward what ends? We move "perplexed but unresisting from (a) the analysis of certain historic regimes of truth as repressive, to (b) the suspicion that all hitherto existing regimes have been in some regard repressive, to (c) the Nietzschean gloss.., that 'discourse is a violence we do to things,' and [thus] all regimes are equally or incommensurably imposed" [49, p. 380]. Giddens notes that this "generates a quiescence" [55, p. 224] and Walzer contends that, since "he cannot point to an alternative.., social criticism must always be a futile enterprise" [26, p.204]. Leo Marx notes that such formulations are "even more technocratic than the distorted Enlightenment ideology" it seeks to displace [61, p. 256]. For instance, electronic communications only make texts and discourses ever more ubiquitous and power and discipline even more effective and ephemeral - now tied more closely to the economic control of the mind and not just the body [62, pp. 159-165]. It is worth noting again that 
Habermas [45; see also the summary in 18] continually explored Foucault's debt to Nietzsche, pointing out the consequent nihilism of his work.

Finally, Brosio [63, pp. 29-31, 216-218, 305-306, 324] argues that power so conceptualized and analyzed is a "lite" form of oppression, inviting a "lite" form of resistance/transgression in rich societies that are insulated from more blunt forms of exploitation elsewhere, out of sight. There are brutal economic realities - they just exist in places like Central America. There are brutal political and governmental realities they just exist in places like Sudan or Colombia. There is a grand narrative in place - the neoliberal conception of the market and Jamesonian culture. Further, democracy is not a question on the table in this formulation. The Foucauldian analysis of power simply provides no basis of challenge, and in fact rules out these realities by bracketing them as "realities" and a function of discourse. Cesar Chavez was apparently wrong: inexpensive lettuce for Americans was a discourse, not the result of economic centralization and exploitation of a transient, vulnerable peasantry in collusion with corporate and governmental exercise of coercion and power. Without a theoretical subject or the ability to locate a locus of power, transgression is (literally) meaningless and hopeless, and social and economic relations are frozen - in stasis.

\section{Foucauldian Problems in LIS}


If, as noted, conceptual imports bring their problems with them, the larger philosophical question is begged: does the use of Foucault's insights and methodologies bring librarianship's theoretical work to similar, nihilistic dead ends? The implications are clearly on the minds of some of these LIS authors:

One does not choose these roles [of librarian or user]; the roles choose the subject [and] from Foucault's point of view, the librarian, or even the library scholar, cannot step outside of this discourse. The point ... is that these arrangements are made possible by an overarching and constitutive discourse of fear [which] make the library possible.... The discourse always comes first [and] one cannot get behind or beyond [it] since the act of transgression, indeed its very idea, is made possible by the actual discourse to be transgressed. [As] a universal and totalizing organizing principle that gives the library its place in modern cultural forms and in institutional action [this would] seem to suggest a certain powerlessness ... [5, p. 323].

This is an essential question that the LIS literature which seeks to place Foucault critically and epistemologically at the center of the field cannot continue to elide. However, in the spirit of engagement this is not played as a trump card, making pointless and ruling out further discussion. Rather, Foucauldian problems within LIS themes are treated as a discourse from the critical vantage points just outlined, and four areas will be 
outlined: avoiding the economic, the selective and self-referential nature of LIS discourse analysis, image, and the unread text of libraries.

Avoiding the Economic

Foucault's animosity toward Marxist categories and concepts may have been an intellectual tonic to an ossified Marxist discourse, but there is the troubling tendency of this form of analysis in librarianship's theoretical literature to largely avoid the influence of economic factors. One finds in this literature only brief references, for instance to the economic status of the profession embedded within a media analysis [22] or the economic power of young people as a market in relation to rock music [28]. Frohmann has gradually moved from an earlier point of dealing (in the spirit of Foucault) with this theme [64] to a more purely Foucauldian posture. His recent book on scientific information and its theories and systems has no index entries for capitalism, information and capitalism, or the economics of information - or anything similar. An unsubtle reading of Foucault (by an LIS author reviewed here) in the endnotes - characterized as "likely quite welcome to corporate sloganeers [in that] the 'meticulous erudition' [and] 'untiring attention' that Foucault attributes to the hard work of exploring intervals between the 'tenets of order' manifested in traditional library classifications are trivialized by reduction to the click of a mouse" [6, p. 285] - is the most explicit he gets in the volume. The closest this literature comes is an analysis of the "discourse of commodification" [4], but the overwhelming emphasis remains on the "analysis of 
culture ... involv[ing] the interpretation of cognitive, semantic, or narrative content which lies hidden within the text" [28, p. 21].

This very much tracks Foucault's thinking given his fundamental suspicion toward grand theories in favor of "local insurrections" and relative conceptions of truth [50, $\mathrm{p}$. 177] and his correlative devaluation of questions concerning who possesses power, by what right, who suffers, and who profits [59, p. 54] - in short, Marxist and economic analyses. However, this is rather a large and obvious gap in an age when immense efforts are pointed toward social and economic transformation necessary for the "new" economy based on information and postindustrial expertise/knowledge, and in an age when media ownership and control is expanding rapidly enough to raise serious concerns about control, monitoring, and the ability for alternate viewpoints to even surface in mass media and libraries $[58 ; 65]$.

The Self-Referential Nature of LIS Discourse Analysis

An LIS discourse that focuses on LIS discourse already suffers from the Foucauldian tautology of power noted at the beginning of this section: it insists that it is a proper and needed object of study, but the means to transcend or improve library discursive practices are largely foreclosed in Foucault's terms. Sometimes this literature simply avoids this question - or points to contradictory statements within Foucault's work which might allow some foothold for hope [see for example $4 ; 27 ; 29 ; 38$ ]. However, the 
greater danger is extreme self-referentiality and irrelevance. The point of LIS discourse analysis becomes LIS discourse analysis:

In Foucault's terms, this article is a statement because it appears in the context of a particular discursive formation. In other words, it appears in this issue of the Library Quarterly [and he] is not interested in ... whether this article is accurate or not [but in] a perspective for the description of the condition in which texts appear" [7, p. 11].

Part of the intent of the texts mentioned here ... is ... to control an argument through the language employed [and] the conclusions reached by the reader. $[\mathrm{T}]$ he discourses both reflect and contribute to the ways we think about LIS and its place in contemporary culture ... and how [it] surface[s] in the professional discourse... [8, p. 77].

$[\mathrm{H}]$ er authority to interpret her own work ... would seem to be somewhat at odds with ... Foucault [in] that meaning/significance is not determined by authors but constructed by readers[, but] one product of these constructive processes ... was a construction of the [prominent LIS] author as the most authoritative interpreter of her own work [66]. 
The shift in LIS's theoretical attention from information system to information user is especially suited to questions of the role of LIS theories in the discursive construction of specific identities... [27, p. 133].

Again, the question is begged: what is the point? One could say that this article is itself a "statement" in this discourse, but I have argued elsewhere that the adoption of a postmetaphysical epistemology (Habermas's in this case) need not preclude (and in fact explains actual historical) change and even improvement in librarianship: meaning, socially and linguistically built up over time, along with the means by which people rationally construct understanding and as social/normative background, provide a basis however currently corrupted - for reflexive self-understanding and democratic political will-formation [1]. In contrast, Foucault in LIS seems to have left us with "strategies without projects" [50, p. 168].

Two further points needs to be made here concerning self-referentiality and authority. First, Frohmann's earlier description of LIS discourse from 1876 to the present as an exercise in power over information and users can certainly be critiqued in its own Foucauldian terms. It appropriates a discourse and describes its boundaries in order to form a "discipline" in the dual Foucauldian sense [42, p. 191]: 1) as an exercise in "discipline" (power) via a methodology, and; 2) as a categorization subsuming the discourse and thus forming the "discipline" of LIS - simultaneously configuring a field of ignorance as he put it. What vantage point of authority does a Foucauldian LIS analysis 
assume that puts it outside of such a critique - and again, toward what ends? Second, this discourse, though prominent, is (to quote Frohmann again) "performed by institutionallyprivileged speakers": LIS professors and those with requisite prestige from other fields who have taken an interest in librarianship. This in itself is not necessarily remarkable, but the problem of self-referentiality is real. One respondent to a study of LIS researchers noted that "we're a small field [and] we all know one another, we all talk to each other, we all go to the same conferences. And perhaps this is why there is not much negative citation; we don't want to give too much criticism to each other" [in 66]. There are other examples, but the point suffices. However, it is the reaction to those outside this circle (an important Foucauldian concept unreflexively utilized in this literature) which is revealing. For instance, an author at some remove who characterized LIS writing as "this incredible stream of garbage" was described as "uncharitable," while two others affiliated with U.S. library schools (and journals in the field) who came to similar conclusions are described much more gingerly [27, p. 122]. A paper by a librarian and education professor (two classic examples of Foucauldian "low epistemological profile") which specifically critiqued positivist conceptions of librarianship from a non-Foucauldian vantage was identified with the a priori positivism of library neutrality [29, p. 412]. Most pointedly, when a library director challenged some of this literature (in this journal), the reaction was swift and thorough $[67 ; 36]$. Foucauldian unconcern with "accuracy" and "truth" went out the window in that case, and again, this literature seems to assume a vantage-less point of authority and critique at times. 
Image

Separated from Habermas's "excitement stylized into the other of reason," the state-of-the-art Foucauldian language and focus on various "texts" seems to settle around an age-old bane of the profession: poor image. While the choice to analyze stereotypes in movies (Party Girl [22], Pagemaster, Sophie's Choice, UHF [5]) and in commercials [30] serves to unpack those images, they still focus on an issue that the field has been rightly criticized for being obsessed with for many years and trivializing of our work and research. (Thistlethwaite's essay "Old Maids and Fairies" captured why the "image problem" bothers us (particularly men) so much: because the "stereotypes read QUEER with a capital Q" [68].) Echoing Brosio, unpacking these popular media images is a "lite" form of transgression, and while amusing, does nothing to challenge the widespread gender discrepancies in images of power, competence, and authority as they relate to technology by librarians and information workers - at least one area where these analyses might have some positive effect [69]. Similarly, one can see the image issue vibrating lightly under the surface of the work that urges the field to come up to speed in terms of more avant garde ideas and methods: "'The field has come relatively late to an awareness of qualitative research... Research in [LIS] has generally been characterized by a loose confederacy of approaches, ...but a serious cultivation of the potential of qualitative research has yet to emerge.' ...Discourse analysis belongs here too..." [27, p. 119]. Elsewhere this same author invokes "lamentations of sterility" which at the same 
time seem to "co-exist happily with ... the extraordinary license enjoyed by LIS theory..." [4, p. 366]. Epistemological naiveté too seems to hurt our image.

The Unread Text of Libraries

Like Foucault's preference for prison designs and manuals for the classification and treatment of prisoners or the insane, Foucauldian LIS picks and chooses its texts about libraries highly selectively: Flaubert's The Temptation of Saint Anthony (along with Foucault's "Fantasia of the Library") [6; 29; 38; 39], Stephen King's The Library Policeman and Isaac Asimov's Forward the Foundation [5], and Umberto Eco's The Name of the Rose [30] are prominent examples. In these texts and their LIS readings, libraries are laden with power, control, fear, and radical contradictions. Utterly absent is what Wiegand has long identified as the under-studied, everyday ubiquity of libraries (there are more public libraries than McDonald's restaurants, three times the number of reference questions in academic libraries than attend college football games, more visits to libraries than national parks in the U.S., etc. [70]) and real people's continual testimony on the importance and centrality of libraries and reading in their lives. American Libraries gathers quotes in a regular column ("Thus Said") and features prominent people who continually repeat these themes: "My real luck was having parents who shared the love of reading and who introduced me to the wonder of the library;" "I'd shut every tavern and church before I'd allow my library to close;" "I applaud the determination of university libraries [because] if students ... cannot see and feel and touch the books that 
human beings have made, written, written in, and read, then they will lose touch with the very essence of what it means to be human;" "More than a building that houses books and data, the library represents a window to the larger world" [Fallon, Russo, Terepka, and Obama in 71, pp. 36, 49].

The Foucauldian answer is of course that these represent their own under analyzed discourse of power, but that is simply too pat, too easy. This is the American, lit-crit Foucault which essentially turns Wiegand on his head: that libraries are such a common-place "good" makes their power discourse all the more sinister and hidden, perhaps even that libraries and reading are more culturally and economically domineering than McDonalds - or television. Libraries in this LIS selection and reading of this literature are equated with fortresses, cathedrals, tombs, crypts, labyrinths, monasteries, otherworldly and intimidating edifices, violence, control, constraint, humiliation, and the borders between coherence and incoherence $[30 ; 29 ; 7 ; 6 ; 39]$. This echoes the weakness noted previously in the critiques of Walzer and Giddens, and the focus represents a choice (and an exercise in power?) to ignore the meaning of mundane text in favor of the exotic, problematic, and contradictory. If, as Poster notes, Foucault cannot justify his choices of topics or texts [19], it is hard to see these LIS authors effectively justifying theirs. These various readings fail in the main to challenge economies and relations of power (via gender or now, surveillance in the age of USAPATRIOT), and they represent only a partial, skewed "reading" of libraries. Again, a Foucauldian tautological ruling out of order is too easy, too self-referential. 
Tom Mann inherently challenges this kind of thinking in his attack on economic and instrumental LIS discourse and management practices which derive from it:

Our profession has apparently forgotten that research libraries will continue to be necessary for ... crucial purposes ... not accomplished by remote storage or massive digitization of books, and not served by transformation of library buildings.... Specifically, those purposes are:

to collect, in print form, ...current imprints that are not freely accessible to everyone online because of copyright restrictions; to make such sources freely and easily available ... within the public spaces defined [as libraries] widely distributed among thousands of communities; to catalog--rather than merely inventory--the books [to] create categorizations, linkages, and webs of conceptual relationships ... while also eliminating irrelevant associations; to facilitate both depth-searching of subject content and systematic recognition discovery ... by means of classified shelving that enables scholars to do focused browsing of contiguous subject-related full texts; to make ... available ... the one ...format ... that promotes ... the actual reading of lengthy narrative and expository texts necessary for conveying 
knowledge and understanding ... and to preserve knowledge records for centuries, not mere decades.

[O]ur leadership, floating at the 50,000 foot level, apparently does not grasp the crucial requirements of scholarship at ground level. ... We are [blind] both to the strengths of real libraries and to the weaknesses of the Internet, and ... are transforming research libraries into their very opposites... [72; see also 73].

Mann's analysis demonstrates that looking at discourse - or a discourse - does not by definition lead to stasis. Critique, challenge, and positive change are possible. His challenge was anticipated by Wiegand who noted that library classification schemes are flawed, but they "constitute one of the few bridges available to all who use them to help link the separate islands of discourse.... Capitalism doesn't necessarily appreciate [all of] this; democracy does" [in 58, p. 48]. Finally, there is an ahistorical aspect to the Foucauldian LIS reading of libraries which echoes the critique outlined by Poster earlier. Historical/institutional changes (dare one say democratization or progress?) and broad social developments (like public education) in which librarianship was embedded or in which librarianship actively participated are entirely absent in this literature. The "text" of librarianship, as read in these terms, does not admit of historical developments or future possibilities. There is, in short, a vast unread part of librarianship which points toward potential, beneficial change and past enabling of readers and patrons. 


\section{Conclusion}

Many of the thinkers used here to critique Foucault (like Poster) do so in order to capture and further his most important and effective insights. Even Habermas, Foucault's most severe critic, acknowledged his influence: "Foucault has most lastingly influenced the Zeitgeist, not least of all because of the seriousness with which he perseveres under productive contradictions. Only a complex thinking produces instructive contradictions" [54, p.107] - a point echoed by Walzer who calls him "importantly wrong" and acknowledges that Foucault has forced us to recognize that there is "no such place [as] a realm of pure value" and there is "no value untouched by power" [26, pp. 193, 209]. In contrast to these acknowledgements of important - but limited - influence, Foucauldian LIS theory lays claim to a sweeping territory:

a grand analysis and one that will take library scholars far beyond their traditional domains ... to situate the library ... within prevailing systems of power and knowledge that constitute and maintain all of the discourses and institutions within contemporary Western civilization. [A] big step, but ... one that library scholarship needs to take in earnest" [5, p. 325].

The LIS writers here are engaged in a project of constructing a viable, critical theory of librarianship. However, a theoretical import which enjoins against possibility and positive change leads to stasis. Foucault's statements, such as "to imagine another 
system is to extend our participation in the present system. ...This need for theory is still part of the system we reject" [74, pp. 230-231], define stasis, and it translates to LIS theory. After thoroughly reviewing and critiquing the problematic (much of which was derived from a Foucauldain perspective) of a variety of discursive and deconstructive theories and theoretical appropriations in librarianship, Day [23, pp. 602-603] can only weakly conclude that

despite such theoretical weaknesses and ... sheer theoretical disasters, the practice of information science has produced successes. Theoretical discourse and practical activity are not, and may not be in any given practice, causally linked; as with medieval medicine, mystical theoretical foundations and practical successes may coexist within what is claimed to be a field of inquiry.

His analysis only leads to more discourse analysis, more deconstruction of essential term/ concepts, and more fragmentation. There is for Day always a larger frame of discourse and domination surrounding us "requiring" it, and there is simultaneously no subject of or ground to define and defend "freedom" - the binary of "necessity."

It may be transgressive to focus on discursive patterns and contradictions in LIS, or deconstruct media images and reveal their embedded discursive power, but Habermas's dismissal of the "capering" and "cynical" intellectual byproducts of a focus on "the refuse 
dumps of civilization ... camouflaged with plastic" is well taken [46, pp. 83, 97]. A variation on an earlier comment is that Foucault's work "seems to be a strategy without a subject" [18, p. 89 (emphasis in original)]. As Walzer put it, "one can't be critical, unless one inhabits some social setting and adopts, however tentatively, its codes and categories. Or unless ... one constructs ... a new setting and works out new codes and categories. Foucault refuses to do either" [26, p. 209]. It is the argument here that Foucault's place at the center of this literature represents, ultimately, not transgression with a purpose, but stasis. The aim is not conservative, but the result is. A Foucauldian reading is only a partial "reading" of the library "text." It is a conceptual import with its own discursive agenda which rules out all or most of the end purposes of such a critique.

Like many of Foucault's critics, I am not content to leave it there. The goal has been to highlight a longstanding problematic within his work that has been analyzed and written about extensively and bring it to bear on that part of librarianship's criticaltheoretical project which utilizes his thinking. As this author has written elsewhere, critical educational scholarship offers an instructive and germane example of a field which has struggled with the push-pull of these ideas and how to productively incorporate them [65]. Toward that end Henry Giroux notes that

rather than negating the modernist concern with public life and critical rationality [we must] provide... the grounds on which to deepen and extend such concerns. [E]ngagements with foundationalism, culture, 
difference, and subjectivity provide the basis for questioning the modernist ideal of what constitutes a decent, humane, and good life. ...Talk about the public must be simultaneously about the discourse of an engaged plurality and critical citizenship ... and conditions that organize public life as a democratic social form rather than as a regime of terror and opposition. [W]hat is being argued for is a language in which different voices and traditions exist and flourish to the degree that they listen to the voices of others, engage in an ongoing attempt to eliminate forms of subjective and objective suffering, and maintain those conditions in which the act of communicating and living extends rather than restricts the creation of democratic public forms [56, pp. 25-27].

If Foucault can thus be enlisted to help, as Hebdige put it [in 75, p. 117], open inquiry, consider formerly inadmissible evidence, and erode domination by experts, then he can help librarianship "enhance... our collective (and democratic) sense of possibility." If, on the other hand, our theory of librarianship radically fragments the field, radically bifurcates theory and practice, and sternly enjoins against a purpose, then possibility is precluded and we are, in the words of the educational philosopher Maxine Greene, foreclosed from "thinking of things as if they could be otherwise" [76, p. 116]. 


\section{References}

1. Buschman, John. "'The Integrity and Obstinacy of Intellectual Creations': Jurgen Habermas and Librarianship's Theoretical Literature." Library Quarterly forthcoming.

2. Pettigrew, Karen E. and McKechnie, Lynne. "The Use of Theory in Information Science Research." Journal of the American Society for Information Science and Technology 52 (January 1, 2001): 62-73.

3. Wolin, Sheldon S. "Political Theory as a Vocation." American Political Science Review 63 (December 1969): 1062-1082.

4. Frohmann, Bernd. "The Power of Images: A Discourse Analysis of the Cognitive Viewpoint." Journal of Documentation 48 (December 1992): 365-386.

5. Radford, Marie L. and Radford, Gary. "Libraries, Librarians, and the Discourse of Fear." Library Quarterly 71 (July 2001): 299-329.

6. Frohmann, Bernd. Deflating Information: From Science Studies to Documentation. Toronto: University of Toronto Press, 2004.

7. Radford, Gary. "Trapped in our Own Discursive Formations: Toward an Archaeology of Library and Information Science." Library Quarterly 73 (January 2003): $1-18$.

8. Budd, John M. and Raber, Douglas. "The Cultural State of the Fin De Millenaire Library." Library Quarterly 68 (January 1998): 55-79. 
9. Dick, Archie L. "Library and Information Science as a Social Science: Neutral and Normative Conceptions." Library Quarterly 65 (April 1995): 216-235.

10. Budd, John M. Knowledge and Knowing in Library and Information Science: A Philosophical Approach. Lanham, MD: Scarecrow Press, 2001.

11. "Final reminder: Call for papers for Library Quarterly Special issue on Discursive Approaches to Information Seeking in Context." Available at $<$ http:// librarycareers.blogspot.com/2006_02-01_librarycareers_archive.html> 12. Foucault, Michel. "History of Systems of Thought." In Language, CounterMemory, Practice: Selected Essays and Interviews, by Michel Foucault, edited by Donald Bouchard, pp. 199-204. Ithaca, NY: Cornell University Press, 1977.

13. Foucault, Michel. The Archaeology of Knowledge. New York: Pantheon, 1972.

14. Foucault, Michel. Discipline and Punish: the Birth of the Prison. New York: Vintage, 1979.

15. Foucault, Michel. "The Order of Discourse." In Untying the Text: a Post-

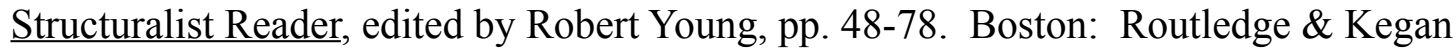
Paul, 1981.

16. Foucault, Michel. "Omnes et Singulatim: Towards a Criticism of 'Political Reason'." In The Tanner Lectures on Human Values II, 1981, edited by Sterling McMurrin, pp. 225-254. Salt Lake City: University of Utah Press, 1981.

17. Poster, Mark. Cultural History and Postmodernity: Disciplinary Readings and Challenges. New York: Columbia University Press, 1997. 
18. Sarup, Madan. An Introductory Guide to Post-structuralism and Postmodernism. Athens: University of Georgia Press, 1989.

19. Poster, Mark. "Foucault, Michel." In The Johns Hopkins Guide to Literary Theory \& Criticism, edited by Michael Groden and Martin Kreiswirth. Baltimore, MD: Johns Hopkins University Press, 1997. Available at < http://www.georgetown.edu/faculty/ irvinem/theory/Foucault-HopkinsGuidetoLitTheory-1997.html >

20. Linn, Ray. A Teacher's Introduction to Postmodernism. Urbana, IL: NCTE, 1996. 21. Kumar, Krishan. "The Post-Modern Condition." In Education: Culture, Economy, and Society, edited by A.H. Halsey, Hugh Lauder, Phillip Brown, and Amy Stuart Wells, pp. 96-112. New York: Oxford University Press, 1997.

22. Radford, Marie L. and Radford, Gary. "Librarians and Party Girls: Cultural Studies and the Meaning of the Librarian." Library Quarterly 73 (January 2003): 54-69.

23. Day, Ronald E. "Poststructuralism and Information Studies." In Annual Review of Information Science and Technology Volume 39, edited by Blaise Cronin, pp. 575-609. Medford, NJ: Learned Information, 2005.

24. Harris, Michael. Review of "Michel Foucault." Library Quarterly 63 (January 1993): $115-116$

25. Wiegand, Wayne A. "Tunnel Vision and Blind Spots: What the Past Tells Us About the Present; Reflections on the Twentieth-Century History of American Librarianship." Library Quarterly 69 (January 1999): 1-32.

26. Walzer, Michael. The Company of Critics: Social Criticism and Political Commitment in the Twentieth Century. New York: Basic Books, 1988. 
27. Frohmann, Bernd. "Discourse Analysis as a Research Method in Library and Information Science." Library and Information Science Research 16 (1994): 119-138.

28. Frohmann, Bernd. "Discourse and Documentation: Some Implications for Pedagogy and Research." Journal of Education for Library and Information Science 42 (Winter 2001): 12-26.

29. Radford, Gary. "Positivism, Foucault, and the Fantasia of the Library:

Conceptions of Knowledge and the Modern Library Experience." Library Quarterly 62 (October 1992): 408-424.

30. Radford, Marie and Radford, Gary. "Power, Knowledge, and Fear: Feminism, Foucault, and the Stereotype of the Female Librarian." Library Quarterly 67 (October 1997): $250-266$.

31. Budd, John M. "Instances of Ideology in Discursive Practice: Implications for Library and Information Science." Library Quarterly 71 (December 2001): 498-517.

32. Tuominen, Kimmo. "User-Centered Discourse: An Analysis of the Subject

Positions of the User and the Librarian." Library Quarterly 67 (October 1997): 350-371.

33. Foucault, Michel. "The Subject and Power." Critical Inquiry 8 (Summer 1982): 777-795.

34. Foucault, Michel. "On Power." In Politics, Philosophy, Culture: Interviews and Other Writings, 1977-1984, by Michel Foucault, edited by Lawrence D. Kritzman, pp. 96-109. New York: Routledge, 1988.

35. Foucault, Michel. "Truth and Power." In The Foucault Reader, edited by Paul Rabinow, pp. 51-75. New York: Pantheon, 1984. 
36. Radford, Gary P. and Budd, John M. "We Do Need a Philosophy of Library and Information Science - We're Not Confused Enough: A Response to Zwadlo." Library Quarterly 67 (July 1997): 315-321.

37. Budd, John M. "An Epistemological Foundation for Library and Information Science." Library Quarterly 65 (July 1995): 295-318.

38. Radford, Gary. "Flaubert, Foucault, and the Biblioteque Fantastique: Toward a Postmodern Epistemology for Library Science." Library Trends 46 (Spring 1998): 616-634.

39. Radford, Gary and Radford, Marie. "Structuralism, Post-Structuralism, and the Library: de De Saussure and Foucault." Journal of Documentation 61 (2005): 60-78. 40. Foucault, Michel. "Fantasia of the Library." In Language, Counter-Memory, Practice: Selected Essays and Interviews, by Michel Foucault, edited by Donald Bouchard, pp. 87-109. Ithaca, NY: Cornell University Press, 1977.

41. Foucault, Michel. "About the Beginning of the Hermeneutics of the Self: Two Lectures at Dartmouth." Political Theory 21 (May 1993): 198-227.

42. Simons, Jon. "Michel Foucault (1926-84)." In Contemporary Critical Theorists: From Lacan to Said, edited by Jon Simons, pp. 185-200. Edinburgh: Edinburgh University Press, 2004.

43. Said, Edward. "Deconstructing the System." New York Times 17 December, 2000. Available at $<$ http://www.nytimes.com/books/00/12/17/reviews/ 001217saidlt.html> 
44. McCarthy, Thomas. "Introduction." In The Philosophical Discourse of Modernity: Twelve Lectures, by Jurgen Habermas, pp. vii-xvii. Cambridge, MA: MIT Press, 1987. 45. Habermas, Jurgen. The Philosophical Discourse of Modernity: Twelve Lectures. Cambridge, MA: MIT Press, 1987.

46. Habermas, Jurgen. "A Philosophico-Political Profile." New Left Review Issue 151 (May/June 1985): 75-105.

47. Habermas, Jurgen. "Modernity Versus Postmodernity." New German Critique 22 (Winter 1981): 3-14.

48. Tate, John. "Posting Modernity to the Past?" Telos 115 (Spring 1999): 79-94.

49. Taylor, Charles. "Connelly, Foucault, and Truth." Political Theory 13 (August 1985): $377-385$.

50. Taylor, Charles. "Foucault on Freedom and Truth." Political Theory 12 (May 1984): 152-183.

51. Foucault, Michel. "What Is Enlightenment?" In The Foucault Reader, edited by Paul Rabinow, pp. 32-50. New York: Pantheon, 1984.

52. Foucault, Michel. "Space, Knowledge, and Power." ." In The Foucault Reader, edited by Paul Rabinow, pp. 239-256. New York: Pantheon, 1984.

53. Foucault, Michel. "Power and Sex." In Politics, Philosophy, Culture: Interviews and Other Writings, 1977-1984, by Michel Foucault, edited by Lawrence D. Kritzman, pp. 110-124. New York: Routledge, 1988. 
54. Habermas, Jurgen. "Taking Aim at the Heart of the Present." In Foucault: A Critical Reader, edited by David Couzens Hoy, pp. 103-108. New York: Basil Blackwell, 1986.

55. Giddens, Anthony. Profiles and Critiques in Social Theory. Berkeley: University of California Press, 1982.

56. Giroux, Henry. "Postmodernism and the Discourse of Educational Criticism." Journal of Education 170 no. 3 (1988): 5-30.

57. Christian, Barbara. "The Race for Theory." Feminist Studies 14 (Spring 1988): $67-79$.

58. Buschman, John E. Dismantling the Public Sphere: Situating and Sustaining Librarianship in the Age of the New Public Philosophy. Westport, CT: Libraries Unlimited/Greenwood, 2003.

59. McCarthy, Thomas. Ideals and Illusions: On Reconstruction and Deconstruction in Contemporary Critical Theory. Cambridge, MA: MIT Press, 1991.

60. Foucault, Michel and Deleuze, Gilles. "Intellectuals and Power." In Language, Counter-Memory, Practice: Selected Essays and Interviews, by Michel Foucault, edited by Donald Bouchard, pp. 205-217. Ithaca, NY: Cornell University Press, 1977. 61. Marx, Leo "The Idea of 'Technology' and Postmodern Pessimism." In Does Technology Drive History? The Dilemma of Technological Determinism, edited by Merritt Smith and Leo Marx, pp. 237-257. Cambridge, Mass.: MIT Press, 1994. 62. Marshall, James. "The Mode of Information and Education: Insights on Critical Theory from Michel Foucault." In Critical Theories in Education: Changing Terrains of 
Knowledge and Politics, edited by Thomas Popkewitz and Lynn Fendler, pp. 145-167.

New York: Routledge, 1999.

63. Brosio, Richard A. Philosophical Scaffolding for the Construction of Critical

Democratic Education. New York: Peter Lang, 2000.

64. Frohmann, Bernd. "The Ethics of Information Science Theory." American Society

for Information Science 55th Annual Meeting, Pittsburgh, PA, 1992.

65. Buschman, John and Brosio, Richard A. "A Critical Primer on Postmodernism:

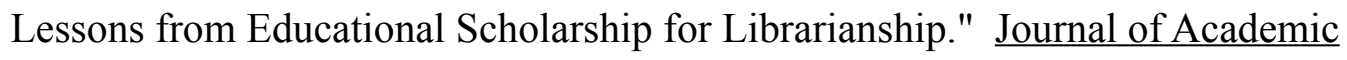

Librarianship forthcoming.

66. Olsson, Michael. "Meaning and Authority: The Social Construction of an 'Author' Among Information Behaviour Researchers." Information Seeking In Context (ISIC) Conference, Dublin, Ireland, September 1-3, 2004.

67. Zwadlo, Jim. "We Don't Need a Philosophy of Library and Information Science We're Confused Enough Already." Library Quarterly 67 (April 1997): 103-121.

68. Buschman, John. Review of Revolting Librarians Redux. Progressive Librarian Issue 23 (Spring 2004): 91-92

69. Dilevko, Juris and Harris, Roma. "Information Technology and Social Relations:

Portrayals of Gender Roles in High Tech Product Advertisements." Journal of the American Society for Information Science 48 (August 1997): 718-727.

70. Wiegand, Wayne. "To Reposition a Research Agenda: What American Studies Can Teach the LIS Community About The Library in the Life of the User." Library Quarterly 73 (October 2003): 369-382. 
71. American Libraries August, 2005.

72. Mann, Thomas. "The Research Library as Place: On the Essential Importance of Collections of Books Shelved in Subject-Classified Arrangements." In The Library as Place: History, Community and Culture, edited by John Buschman and Gloria Leckie. Westport, CT: Libraries Unlimited, 2006 forthcoming.

73. Mann, Thomas. "The Importance of Books, Free Access, and Libraries as Places and the Dangerous Inadequacy of the Information Science Paradigm." Journal of Academic Librarianship 27 (July 2001): 268-281.

74. Foucault, Michel. "Revolutionary Action: 'Until Now'." In Language, CounterMemory, Practice: Selected Essays and Interviews, by Michel Foucault, edited by Donald Bouchard, pp. 218-233. Ithaca, NY: Cornell University Press, 1977.

75. Giroux, Henry. "Crossing the Boundaries of Educational Discourse: Modernism, Postmodernism, and Feminism." In Education: Culture, Economy, and Society, edited by A.H. Halsey, Hugh Lauder, Phillip Brown, and Amy Stuart Wells, pp. 113-130. New York: Oxford University Press, 1997.

76. Greene, Maxine. Variations on a Blue Guitar: the Lincoln Center Institute

Lectures on Aesthetic Education. New York: Teachers College Press, 2001. 